\section{Assessment of the fresh self- compacting concrete properties utilizing different types of additives}

AbdulkadeR EL MIR - BME Department of Construction Materials and Technologies - abdelkader.elmir@hotmail.com

Salem Georges NEHME - BME Department of Construction Materials and Technologies - sgnehme@yahoo.com

Érkezett: 2017. 08. 18. - Received: 18. 08. 2017. - https://doi.org/10.14382/epitoanyag-jsbcm.2017.14

\begin{abstract}
Self-compacting concrete (SCC) is characterized by unique workability properties. Stagnation or segregation of SCC must be avoided to obtain a homogenous and stable mixture. When SCC is produced, it is essential that the concrete has all the adequate fresh properties at the time of placement. For a successful and reliable application of SCC, the predication of SCC fresh state properties is of crucial importance. This predictability is determined by the sensitivity of the rheological properties towards the affecting parameters in the mixture composition. Experimental work was conducted to clarify the effects of the volumetric water to powder ratio and additives on the behavior of SCC from the rheological point of view. Therefore, the aim of this paper is to analyze the effect of different types of additives and paste contents on the fresh state response of SCC; powder type. It was found that the additives can greatly influence the concrete workability. Along that, an extension of the workability window of SCC is updated according to the acceptance criterion for.
\end{abstract}

Keywords: Self-compacting concrete; Fresh properties; Sustainability; Additives

Kulcsszavak: Öntömörödô beton; Frissbeton jellemzők; Fenntarthatóság; Kiegészítô anyagok
Abdulkader EL MIR MSc Civil Engineer, PhD student at BME, Department of Construction Materials and Technologies. Fields of interest: porosity of concrete, self compacting concretes, high performance concretes.

Salem Georges NEHME MSc Civil Engineer, PhD, Associate Professor at BME, Department of Construction Materials and Technologies. Fields of interest: concrete technology, mass concrete, self-compacting concrete, fibre reinforced concrete, quality control of building materials, non-destructive testing, reinforced concrete structures, recycling of building materials.

\section{Introduction}

Self-compacting concrete (SCC) was developed to meet the durability requirements of concrete structures and tackle the casting difficulties in challenging geometries [1].

The primary fresh properties of SCC have been the filling ability, passing ability and segregation resistance. These properties must be taken into consideration in the design phase of SCC. The essential rheological properties of SCC have been based on low yield stress, moderate viscosity and retention of the kinetic energy of the flowable mixture by reducing the content of coarse aggregates. These measures have been required to reach the targeted filling ability, viscosity and segregation resistance. A low yield stress is achieved by the use of adequate dosages of superplasticizer. The flow characteristics are further modified by changing the aggregate volume fraction, coarse-to-fine aggregate volume, and the composition of the other ingredients. The viscosity has been controlled by the contents of the free water, superplasticizer, and the volume fraction of the solids in the mixture. The basic strategies for ensuring a moderate viscosity are based on either inclusion of high amounts of powder materials; i.e. total content of cementitious materials (referred to as powder type SCC) or addition of viscosity modifier agents (referred to as VMA type SCC) [2-5].

The filling ability is a fresh property of SCC that permits it to flow into the formwork under self-weight, and without vibration or any other means of consolidation. SCC filling ability is controlled through its rheological parameters such as the yield stress and the plastic viscosity. In general, high range water reducing admixture (HRWRA) improves the filling ability of SCC by reducing the yield stress and plastic viscosity. On the other hand, extreme dosages of HRWRA could result in very high fluidity that may cause concrete segregation. The use of additives is a great alternative to improve the segregation resistance. Therefore, the stability of the mixture could be maintained along with a good filling ability. Additives such as ground granulated blast-furnace slag, metakaolin (MK), silica fume (SF), fly ash and others have been used to produce SCC with a good filling ability [4-7].

Passing ability has been defined as the ability of fresh SCC to flow through small openings and fill the spaces within the reinforcements. In case of heavily reinforced structures, an adequate passing ability of SCC enables it to be placed and consolidated through dense reinforcing bars without any aggregate blockage [4]. The filling and passing ability have been directly connected. Also, the passing ability is affected by the number and spacing of the reinforcing bars. A good passing ability can be achieved by increasing the filling ability of fresh concrete and by limiting the segregation of coarse aggregates. Table 1 summarizes the slump flow classes according to EFNARC recommendations and European standards $[4,7]$.

\begin{tabular}{cc} 
Slump flow classes & Mean slump flow diameter $(\mathbf{m m})$ \\
\hline SF1 & $550-650$ \\
\hline SF2 & $660-750$ \\
\hline SF3 & $760-850$
\end{tabular}

Table 1. Slump flow classes [4, 7]

1. táblázat Roskadási terülési osztályok [4, 7] 
The segregation resistance of SCC has been defined as its ability to remain uniform during and after placement without any loss of stability due to bleeding, mortar separation and coarse aggregate settlement $[2,4]$. In particular, the distortion of aggregates becomes non-uniform if SCC did not have the necessary segregation resistance. A good segregation resistance of SCC could be obtained by the proper selection of material constituents and fractions. SCC with good segregation resistance quality is characterized by a high amount of powder material, a limited content of well-graded coarse aggregates, a small nominal maximum size of aggregate, and a low water to binder ratio [2,3]. Also, a viscosity modifying agent could assist in the segregation resistance of SCC. The characterization of the viscosity of SCC could be determined using the V-funnel time test. The test procedure has been clearly described in EFNARC guidelines [4].

Since there has been a large amount of recommendations and guidelines in the literature. Table 2 and 3 help to summarize the viscosity classes (VF).

\begin{tabular}{cc} 
Viscosity class & V-funnel time (s) \\
\hline VF1 & $\leq 8$ \\
\hline VF2 & $9-25$
\end{tabular}

Table 2. Viscosity classification for V-funnel time test [4, 7]

2. táblázat Viszkozitási osztályok tölcséres kifolyási vizsgálat alapján [4, 7]

\begin{tabular}{cc} 
References & Recommended V-funnel time (s) \\
\hline BRL 1801 recommendations [8] & $9-25$ \\
\hline EFNARC guidelines [5] & $6-12$ \\
\hline Domone [9] & $3-15$
\end{tabular}

Table 3. Recommendation for V-funnel time by several authors

3. táblázat Tölcséres kifolyási idő javaslatok különbözö szakirodalmi forrásokban

During the development of the mixture composition of SCC, the optimum workability ranges were established for the fresh state. Fig. 1 illustrates the workability ranges as suggested by DAfStb [10]. This could help to limit the targeted values based on the upper and lower limits of the slump flow and for the $\mathrm{V}$-funnel flow time.

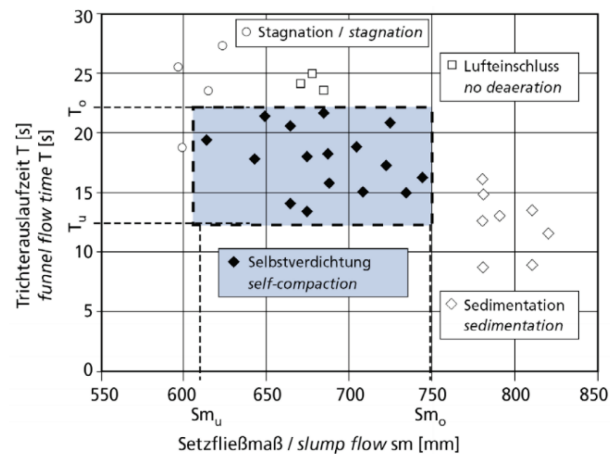

Fig. 1. Processing window for SCC as suggested by DAfStb [10]

1. ábra DAfStb [10] javaslat öntömörödő beton optimális reológiai jellemzöire

\section{Experimental work}

\subsection{Materials, mix design and testing methods}

A total of seventy-two SCC mixtures were designed and placed with common constant and variable parameters to obtain an objective evaluation between the fresh properties. Local natural quartz river sand and gravel with a maximum nominal size of $16 \mathrm{~mm}$ were used in the mixtures. Blast furnace slag cement CEM III/A 32.5 R (C) with a compressive strength grade of $32.5 \mathrm{MPa}$ and a clinker content in the range of 41-58 wt\% was applied for the present study. MK and SF were the supplementary cementitious materials (SCMs) implemented separately to enrich the mechanical properties. Waste perlite powder (WPP) originating from raw perlite rock was used as a filler material for SCC. Two types of WPP, which mainly differed in terms of their specific surface areas (WPP-C and WPP-SZ), were generated from cutting the raw perlite rock and applied with the following content (75\% WPP-C and 25\% WPP-SZ). Limestone powder (LP) was the non-pozzolanic filler applied in this study. The physical and chemical compositions of the mentioned fine materials are shown in Table 4, and grading fractions are provided in Fig. 2. A HRWRA, Sika Viscocrete 5 , was used and adjusted to keep an SF3 slump flow class in a range of 740-850 $\mathrm{mm}$ [7].

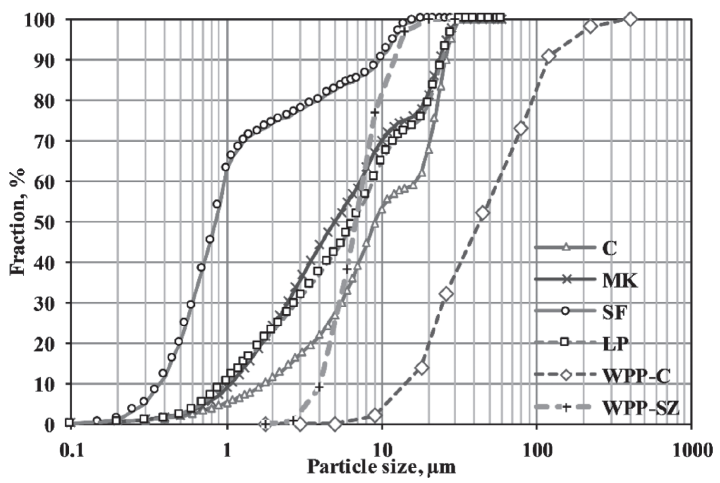

Fig. 2. Particle size distribution of the cement (C), metakaolin (MK), silica fume $(S F)$, limestone powder (LP), waste perlite powder (WPP-C) and waste perlite powder (WPP-SZ)

2. ábra Szemeloszlási görbék; cement (C), metakaolin (MK), szilikapor (SF), mészköpor (LP), hulladék perlit C (WPP-C), hulladék perlit SZ (WPP-SZ)

\begin{tabular}{|c|c|c|c|c|c|c|}
\hline $\begin{array}{l}\text { Chemical } \\
\text { composition }\end{array}$ & C & MK & SF & $L P$ & WPP-C & WPP-SZ \\
\hline $\mathrm{SiO}_{2}$ & 25.53 & 52.79 & 95.09 & 5.63 & 73.80 & 73.2 \\
\hline $\mathrm{Al}_{2} \mathrm{O}_{3}$ & 6.3 & 42.07 & 0.24 & 1.4 & 13.80 & 16.6 \\
\hline $\mathrm{Fe}_{2} \mathrm{O}_{3}$ & 2.29 & 1.25 & 0.06 & 0.9 & 1.57 & 2.6 \\
\hline $\mathrm{CaO}$ & 55.59 & 0.37 & 0.91 & 50.32 & 1.17 & 1.06 \\
\hline MgO & 4.05 & 0.38 & 0.32 & 0.65 & 0.11 & 0.2 \\
\hline $\mathrm{SO}_{3}$ & 2.34 & $<0.01$ & 0.07 & 0.08 & - & - \\
\hline $\mathrm{K}_{2} \mathrm{O}$ & 0.78 & 1.22 & 0.51 & 0.29 & 4.01 & 3.5 \\
\hline $\mathrm{Na}_{2} \mathrm{O}$ & 0.33 & 0.02 & 0.2 & 0.07 & 2.66 & 1.5 \\
\hline $\mathrm{TiO}_{2}$ & 0.28 & 0.2 & $<0.01$ & 0.08 & 0.083 & 0.09 \\
\hline $\mathbf{P}_{2} \mathbf{O}_{5}$ & 0.03 & 0.06 & 0.07 & 0.02 & - & - \\
\hline \multicolumn{7}{|l|}{$\begin{array}{l}\text { Physical } \\
\text { properties }\end{array}$} \\
\hline Specific gravity & 3.1 & 2.6 & 2.35 & 2.69 & 2.33 & 2.33 \\
\hline $\begin{array}{l}\text { Specific surface } \\
\text { area }\left(\mathrm{cm}^{2} / \mathrm{g}\right)\end{array}$ & 3450 & 15244 & 20450 & 3470 & 843.3 & 4159 \\
\hline $\begin{array}{l}\text { Loss on } \\
\text { ignition (\%) }\end{array}$ & 2.15 & 1.59 & 2.49 & 40.55 & 2.8 & 1.21 \\
\hline
\end{tabular}

Table 4. Chemical and physical characteristics of binders and filler materials 4. táblázat Alkalmazott anyagok kémiai és fizikai jellemzői 


\begin{tabular}{|c|c|c|c|c|c|c|c|c|c|c|}
\hline Mix ID & $w / c_{a}$ & $w / p_{b}$ & $a / p_{c}$ & $\begin{array}{l}\mathrm{MK} \\
\mathrm{kg} / \mathrm{m}^{3}\end{array}$ & $\begin{array}{c}\mathrm{SF} \\
\mathrm{kg} / \mathrm{m}^{3}\end{array}$ & $\begin{array}{l}\text { LP or WPP } \\
\mathrm{kg} / \mathrm{m}^{3}\end{array}$ & $\begin{array}{l}\text { HRWRA, } \\
\mathrm{kg} / \mathrm{m}^{3}\end{array}$ & $\begin{array}{c}\text { V-funnel time, } \\
\text { s }\end{array}$ & $\begin{array}{c}\text { Slump flow, } \\
\mathrm{mm}\end{array}$ & Reference \\
\hline T1 & 0.56 & 0.84 & 2.7 & & & 300 & 2.24 & 7.5 & 730 & - \\
\hline T2 & 0.50 & 0.85 & 2.8 & & & 260 & 2.34 & 14.6 & 580 & - \\
\hline T3 & 0.45 & 0.85 & 2.8 & & & 220 & 2.60 & 8.5 & 630 & - \\
\hline SCC-1 & 0.56 & 0.84 & 2.7 & 40 & & 260 & 2.20 & 9.5 & 610 & [13] \\
\hline SCC-2 & 0.50 & 0.84 & 2.8 & 40 & & 220 & 2.70 & 7.7 & 720 & [13] \\
\hline scc-3 & 0.45 & 0.85 & 2.8 & 40 & 40 & 180 & 2.80 & 9.3 & 690 & [13] \\
\hline ScC-4 & 0.56 & 0.83 & 2.7 & & 40 & 260 & 4.00 & 8.2 & 710 & [13] \\
\hline SCC-5 & 0.50 & 0.84 & 2.7 & & 40 & 220 & 3.60 & 12.0 & 725 & [13] \\
\hline scc-6 & 0.45 & 0.85 & 2.8 & & & 180 & 3.20 & 9.5 & 720 & [13] \\
\hline T4 & 0.56 & 0.90 & 3.0 & & & 260 & 0.96 & 16.5 & 530 & - \\
\hline T5 & 0.50 & 0.91 & 3.1 & & & 220 & 1.26 & 9.5 & 630 & - \\
\hline T6 & 0.45 & 0.92 & 3.1 & & & 180 & 3.20 & 3.7 & 890 & - \\
\hline scc-7 & 0.56 & 0.90 & 3.0 & 40 & & 220 & 2.40 & 13.2 & 680 & [13] \\
\hline SCC-8 & 0.50 & 0.91 & 3.0 & 40 & & 180 & 2.63 & 6.8 & 820 & [13] \\
\hline SCC-9 & 0.45 & 0.92 & 3.1 & 40 & & 140 & 4.00 & 7.0 & 850 & [13] \\
\hline ScC-10 & 0.56 & 0.89 & 3.0 & & 40 & 220 & 2.88 & 10.8 & 835 & [13] \\
\hline SCC-11 & 0.50 & 0.90 & 3.0 & & 40 & 180 & 3.13 & 8.4 & 835 & [13] \\
\hline SCC-12 & 0.45 & 0.91 & 3.0 & & 40 & 140 & 3.70 & 9.9 & 820 & [13] \\
\hline R1 & 0.56 & 0.84 & 2.7 & & & 300 & 3.04 & 5.0 & 800 & {$[11,14]$} \\
\hline R2 & 0.50 & 0.85 & 2.8 & & & 260 & 3.06 & 6.3 & 795 & {$[11,14]$} \\
\hline R3 & 0.45 & 0.85 & 2.8 & & & 220 & 3.56 & 5.9 & 790 & {$[11,14]$} \\
\hline M1 & 0.56 & 0.84 & 2.7 & 40 & & 260 & 3.36 & 7.1 & 775 & {$[11,14]$} \\
\hline M2 & 0.50 & 0.84 & 2.8 & 40 & & 220 & 3.96 & 8.6 & 800 & {$[11,14]$} \\
\hline M3 & 0.45 & 0.85 & 2.8 & 40 & & 180 & 4.40 & 11.0 & 755 & {$[11,14]$} \\
\hline s1 & 0.56 & 0.83 & 2.7 & & 40 & 260 & 5.44 & 5.3 & 765 & {$[11,14]$} \\
\hline s2 & 0.50 & 0.84 & 2.7 & & 40 & 220 & 4.86 & 6.3 & 780 & {$[11,14]$} \\
\hline s3 & 0.45 & 0.85 & 2.8 & & 40 & 180 & 5.20 & 6.7 & 770 & {$[11,14]$} \\
\hline R4 & 0.56 & 0.90 & 3.0 & & & 260 & 1.92 & 5.7 & 740 & {$[11,12]$} \\
\hline R5 & 0.50 & 0.91 & 3.1 & & & 220 & 2.02 & 5.4 & 760 & {$[11,12]$} \\
\hline R6 & 0.45 & 0.92 & 3.1 & & & 180 & 2.72 & 4.6 & 780 & [11] \\
\hline M4 & 0.56 & 0.90 & 3.0 & 40 & & 220 & 2.72 & 9.7 & 775 & {$[11,12]$} \\
\hline M5 & 0.50 & 0.91 & 3.0 & 40 & & 180 & 2.92 & 10.3 & 780 & {$[11,12]$} \\
\hline M6 & 0.45 & 0.92 & 3.1 & 40 & & 140 & 4.00 & 8.6 & 810 & [11] \\
\hline S4 & 0.56 & 0.89 & 3.0 & & 40 & 220 & 2.88 & 6.3 & 760 & [11] \\
\hline S5 & 0.50 & 0.90 & 3.0 & & 40 & 180 & 3.17 & 5.0 & 770 & [11] \\
\hline s6 & 0.45 & 0.91 & 3.0 & & 40 & 140 & 3.76 & 5.1 & 790 & [11] \\
\hline R7 & 0.56 & 1.01 & 3.5 & & & 200 & 1.74 & 5.2 & 780 & [11] \\
\hline R8 & 0.50 & 1.03 & 3.6 & & & 160 & 1.55 & 7.7 & 750 & [11] \\
\hline R9 & 0.45 & 1.04 & 3.6 & & & 120 & 1.76 & 5.9 & 770 & [11] \\
\hline M7 & 0.56 & 1.01 & 3.5 & 40 & & 160 & 2.27 & 7.5 & 770 & [11] \\
\hline M8 & 0.50 & 1.02 & 3.6 & 40 & & 120 & 2.34 & 8.7 & 785 & [11] \\
\hline M9 & 0.45 & 1.03 & 3.6 & 40 & & 80 & 2.84 & 9.7 & 800 & [11] \\
\hline s7 & 0.56 & 1.00 & 3.5 & & 40 & 160 & 2.31 & 6.7 & 765 & [11] \\
\hline S8 & 0.50 & 1.01 & 3.5 & & 40 & 120 & 2.34 & 6.0 & 780 & [11] \\
\hline s9 & 0.45 & 1.02 & 3.6 & & 40 & 80 & 2.72 & 3.6 & 850 & [11] \\
\hline NA1 & 0.56 & 0.84 & 2.7 & & & 300 & 3.68 & 4.9 & 790 & [14] \\
\hline NA2 & 0.50 & 0.85 & 2.8 & & & 260 & 3.42 & 6.1 & 760 & [14] \\
\hline NA3 & 0.45 & 0.85 & 2.8 & & & 220 & 3.92 & 6.1 & 780 & [14] \\
\hline MA1 & 0.56 & 0.84 & 2.7 & 40 & & 260 & 4.80 & 9.5 & 790 & [14] \\
\hline
\end{tabular}




\begin{tabular}{|c|c|c|c|c|c|c|c|c|c|c|}
\hline Mix ID & $w / c_{a}$ & $w / p_{b}$ & $a / p_{c}$ & $\begin{array}{l}\mathrm{MK} \\
\mathrm{kg} / \mathrm{m}^{3}\end{array}$ & $\begin{array}{c}\mathrm{SF} \\
\mathrm{kg} / \mathrm{m}^{3}\end{array}$ & $\underset{\mathrm{kg} / \mathrm{m}^{3}}{\text { LP or } \mathrm{WPP}_{\mathrm{d}}}$ & $\begin{array}{l}\text { HRWRA, } \\
\mathrm{kg} / \mathrm{m}^{3}\end{array}$ & $\begin{array}{c}\text { V-funnel time, } \\
\text { s }\end{array}$ & $\begin{array}{c}\text { Slump flow, } \\
\mathrm{mm}\end{array}$ & Reference \\
\hline MA2 & 0.50 & 0.84 & 2.7 & 40 & & 220 & 5.76 & 11.2 & 800 & [14] \\
\hline МАЗ & 0.45 & 0.85 & 2.8 & 40 & & 180 & 6.20 & 10.1 & 790 & [14] \\
\hline SA1 & 0.56 & 0.83 & 2.7 & & 40 & 260 & 4.64 & 6.6 & 750 & [14] \\
\hline SA2 & 0.50 & 0.84 & 2.7 & & 40 & 220 & 5.04 & 5.9 & 770 & [14] \\
\hline SA3 & 0.45 & 0.85 & 2.8 & & 40 & 180 & 4.80 & 6.4 & 760 & [14] \\
\hline N1-P1 & 0.56 & 0.78 & 2.6 & & & 300 & 7.17 & 8.0 & 850 & [15] \\
\hline N2-P1 & 0.50 & 0.79 & 2.7 & & & 260 & 9.31 & 7.6 & 825 & [15] \\
\hline N3-P1 & 0.45 & 0.81 & 2.7 & & & 220 & 7.57 & 10.1 & 780 & [15] \\
\hline M1-P1 & 0.56 & 0.78 & 2.6 & 40 & & 260 & 7.65 & 10.3 & 760 & [15] \\
\hline M2-P1 & 0.50 & 0.80 & 2.7 & 40 & & 220 & 8.10 & 12.5 & 725 & [15] \\
\hline M3-P1 & 0.45 & 0.81 & 2.7 & 40 & & 180 & 8.40 & 8.3 & 840 & [15] \\
\hline S1-P1 & 0.56 & 0.78 & 2.6 & & 40 & 260 & 7.58 & 5.0 & 810 & [15] \\
\hline S2-P1 & 0.50 & 0.79 & 2.7 & & 40 & 220 & 7.20 & 7.8 & 750 & [15] \\
\hline S3-P1 & 0.45 & 0.81 & 2.7 & & 40 & 180 & 10.56 & 8.7 & 780 & [15] \\
\hline N1-P2 & 0.56 & 0.84 & 2.9 & & & 260 & 6.40 & 6.1 & 785 & {$[12,15]$} \\
\hline N2-P2 & 0.50 & 0.85 & 3.0 & & & 220 & 7.56 & 5.5 & 800 & {$[12,15]$} \\
\hline N3-P2 & 0.45 & 0.87 & 3.0 & & & 180 & 7.96 & 11.7 & 790 & [15] \\
\hline M1-P2 & 0.56 & 0.84 & 2.9 & 40 & & 220 & 7.42 & 8.6 & 800 & {$[12,15]$} \\
\hline M2-P2 & 0.50 & 0.86 & 3.0 & 40 & & 180 & 8.10 & 6.4 & 790 & {$[12,15]$} \\
\hline M3-P2 & 0.45 & 0.88 & 3.0 & 40 & & 140 & 8.40 & 7.9 & 765 & [15] \\
\hline S1-P2 & 0.56 & 0.84 & 2.9 & & 40 & 220 & 7.04 & 5.5 & 785 & [15] \\
\hline S2-P2 & 0.50 & 0.86 & 2.9 & & 40 & 180 & 7.95 & 8.1 & 770 & [15] \\
\hline S3-P2 & 0.45 & 0.87 & 3.0 & & 40 & 140 & 8.88 & 8.0 & 790 & [15] \\
\hline
\end{tabular}

Table 5. Mixtures parameters

5. táblázat Keverék összetételek

To better imitate SCC types used in practice, several factors were considered in the mix design, including the total fine content (sum of cement, fillers, and SCM), SCMs, and filler type. The cement content $\left(320,360,400 \mathrm{~kg} / \mathrm{m}^{3}\right)$, total fine content $(620,580,520) \mathrm{kg} / \mathrm{m}^{3}$ and SCM (none, 40 $\mathrm{kg} / \mathrm{m}^{3}$ ) dosages were set as variables. Aggregate particle-size distribution (three nominal grading fractions) was used as: sand $0 / 4 \mathrm{~mm}(45 \%)$, small gravel $4 / 8 \mathrm{~mm}(25 \%)$, and medium gravel $8 / 16 \mathrm{~mm}(30 \%)$. The amount of water (W), $180 \mathrm{~kg} / \mathrm{m}^{3}$ was held as constant parameters. The mixture compositions of all the studied concretes is summarized in Table 5. In this study, the cement was defined as the main binder, with MK or SF as the SCMs, and WPP or LP as filler materials.

Because of the scope of the comparison, parameters related to the rheological properties of SCC mixtures were collected from previous studies [11-15].

To examine the adequacy of SCC mixtures deformability and viscosity, slump flow diameter and V-funnel time tests were carried out according to European Standards [16-17]. Refereeing to EFNARC guidelines for SCC [4], the aim of the study was to obtain a slump flow criterion which belong to SF3 category. The latter could be achieved by the proper addition of HRWRA and maximum aggregate size of $16 \mathrm{~mm}$.

$\mathrm{X}_{\mathrm{a}}$ : water to cement ratio by weight; $\mathrm{X}_{\mathrm{b}}$ : volumetric water to powder ratio; $\mathrm{X}_{\mathrm{c}}$ : Volumetric aggregates to powder ratio; $\mathrm{X}_{\mathrm{d}}$ : Mixtures with WPP filler are those from N1-P1 to S3-P2

\section{Range of SCC- "Window solution"}

According to the measures from Table 5, a processing window similar to Fig. 1 for the studied SCC mixtures was derived. Note that all studied mixtures were having the same grading fraction of aggregates with a maximum nominal size of $16 \mathrm{~mm}$. Based on the positively evaluated SCC mixtures given in Table 5 and the limitation given by EFNARC [4], an update for the processing window has been created (Fig. 3). This was done in four directions. First, the V-funnel time was enlarged to $14 \mathrm{~s}$, to account for the higher friction and viscous SCC mixtures. Stagnation was noticed by visual inspection when the $\mathrm{V}$-funnel time was greater than $14 \mathrm{~s}$ and the slump flow diameter was less than $600 \mathrm{~mm}$. These mixtures were lacking the flow ability characteristic of SCC. Referring to Fig. 4, cases with stagnation corresponded to mixtures with low volumetric water to powder ratio (Mixtures T2 and T4; see Table 5), and by that, enhancing the plastic viscosity of the concrete. However these mixtures were reproduced with the same mixture composition but with a higher content of HRWRA (Mixtures R2 and R4), providing adequate flow ability and viscosity properties. Therefore, the requirement of $\mathrm{V}$-funnel time greater than $14 \mathrm{~s}$ and slump flow less than $600 \mathrm{~mm}$ might be an appropriate limitation for a highly viscous SCC. Note that this workability window was applied to the range of temperature around $20^{\circ} \mathrm{C}$.

On the other hand, the slump flow axis is enlarged up to $850 \mathrm{~mm}$, to account for the highly flow able mixtures. When 
it comes to mixtures holding a V-funnel time less than $4 \mathrm{~s}$, segregation of concrete was visually observed. The V-funnel time axis is enlarged also in the direction of shorter funnel times. Here at least, the mark of $4 \mathrm{~s}$ should be included as lower funnel time limit. It has been shown that SCC mixtures with low V-funnel time values, as low as $4.6 \mathrm{~s}$ (Mixture R6), could be successfully produced while also fulfilling all other requirements. This is of special relevance in particular for mixtures with low yield stress, thus with large slump flows.

\section{$\circ$ Self-compacting $\triangle$ Stagnation $\square$ Segregation}

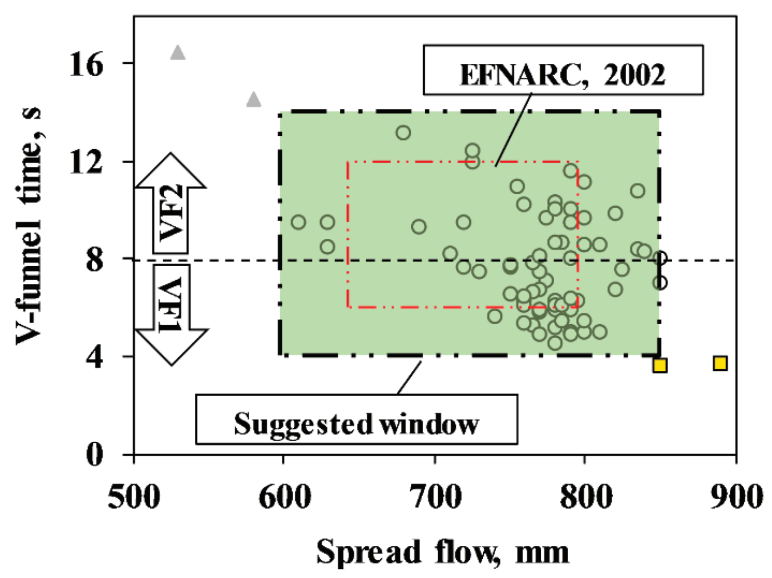

Fig. 3. Suggested processing window for SCC (corresponding data are collected from Table 5) in terms of V-funnel time and slump flow (in green); The red window corresponds to EFNARC limitations [4]

3. ábra Javasolt SCC reológiai jellemzők (az 5. táblázat adatai alapján) tölcséres kifolyási vizsgálatra és roskadási terülésre (zöld színnel); a piros vonallal határolt mezö EFNARC [4] javaslat

$\circ$ Self-compacting $\triangle$ Stagnation $\square$ Segregation

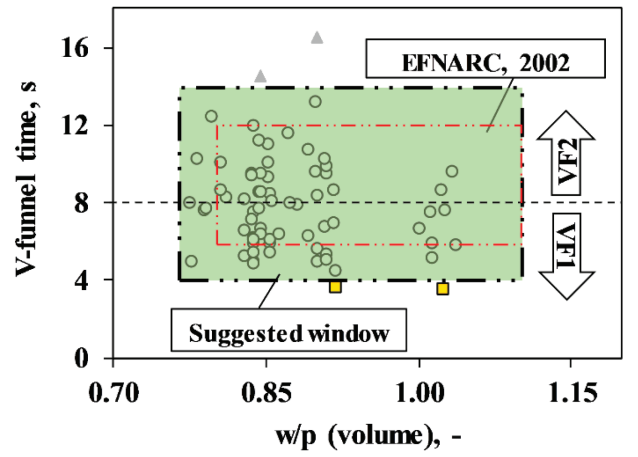

Fig. 4. Ssuggested processing window for SCC (corresponding data are collected from Table 5) in terms of V-funnel time and volumetric water to powder ratio (in green); The red window corresponds to EFNARC limitations [4]

4. ábra Javasolt SCC reológiai jellemzők (az 5. táblázat adatai alapján) tölcséres kifolyási vizsgálatra és térfogat szerinti víz-kötőanyag arányra vonatkozóan (zöld színnel); a piros vonallal határolt mezö EFNARC [4] javaslat

The workability ranges for all collected SCC mixtures are shown in Fig. 4 in terms of their volumetric water to powder ratio and V-funnel time. These mixtures differ in the total powder content, water to cement ratio, and different types of fillers and SCMs (see Table 5). It can be noticed that the workability ranges fluctuate between 750 and $850 \mathrm{~mm}$ since the targeted slump flow classification was SF3 for the following mixtures (starting with mixture "R1" to S3-P2; see Table 5). The exact position of the targeted workability highly depended on the implemented materials and their physical properties.
EFNARC guidelines [3] classified the viscosity of SCC into two classes (see Table 3), Figs. 3 and 4 compared all mixtures that were arranged according to their viscosity class (VF1 or VF2) [3]. It can be noticed that several mixtures shared the same slump flow value but with a different $\mathrm{V}$-funnel time. For instance, if SCC mixture containing MK (mixture M2) or SF (mixture S2) were compared with their corresponding reference mixture $\mathrm{R} 2$, almost a common slump flow diameter $(800 \pm 20 \mathrm{~mm})$ is shown yet with significant difference in the $\mathrm{V}$-funnel time value. MK enhanced the plastic viscosity of the mixture by $36 \%$ in $\mathrm{V}$-funnel time, while adding SF does not appear to have any effect on the viscosity. Same response pattern is noticed for mixtures M5 and S5 as compared with mixture R5. The high cohesiveness of MK bearing mixtures seemed to be the reason for the high $\mathrm{V}$-funnel time. On the other hand, shorter $\mathrm{V}$-funnel times were recorded in SF incorporated mixtures. This could be explained by the ball bearing effect and additional lubrication provided by spherical and smooth-textured of SF particles. This finding is consistent with the following references [18-20].

To avoid the risk of segregation in SCC from excess amount of HRWRA, Fig. 5 shows a curve where the minimum amount of HRWRA is indicated in accordance with the volumetric water to powder ratio derived from the data's in Table 5. The replacement of aggregates by fine powders (lower volumetric water to powder ratio) increased the HRWRA demand of when compared to mixtures with higher volumetric water to powder ratio. The risk of obtaining very viscous, unworkable SCC mixture could be reduced by increasing the w/p. The causes of the increase in HRWRA demand upon SCMs were studied by several researches [19]. They concluded that the very small size SCMs particles with high specific surface area, tendeed to agglomerate resulting in a high demand of HRWRA. Thereby, excess of HRWRA deflocculated the fine agglomerate particle, and lubricated the flowing system.

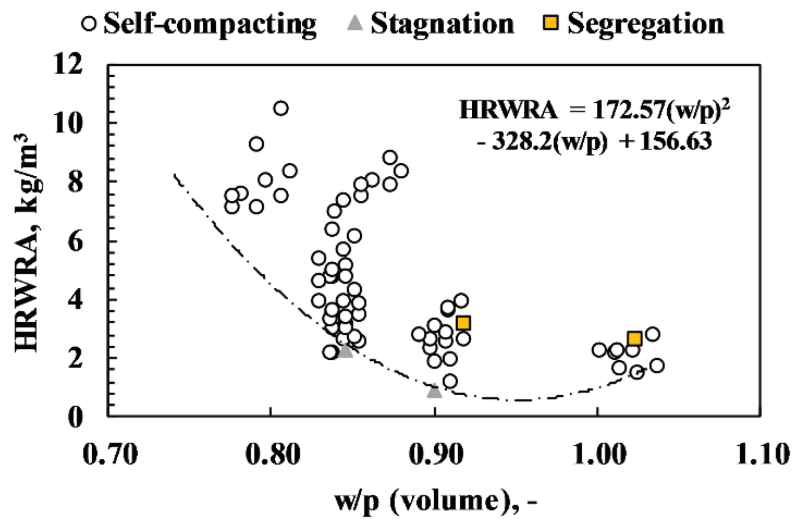

Fig. 5. Relationship between the high range water reducing admixture content and the volumetric water to powder ratio

5. ábra Összefüggés a folyósítószer adagolás és a térfogat szerinti víz-kötőanyag arány között

\section{Conclusions}

Self-compacting concrete (SCC) is sensitive to small changes in the material properties and proportions used in the mix design. An experimental approach for assessing the fresh 
properties of SCC has been developed which represents the workability window of SCC in a diagram (slump flow diameter as a measure of the flow ability and the V-funnel flow time as a measure of the viscosity).

Based on the effects of the different mix design parameters (Volumetric water-to-powder ratio, high range water reducing admixture content and additives) on the fresh properties of examined SCC mixtures, the following conclusions could be drawn:

1. The optimum ranges of workability for self-compacting concrete SCC and its corresponding limits (stagnation and segregation) have to be tested and specified for the adequate fresh behaviour. That's could be achieved by varying the volumetric water to powder ratio and high range water reducing admixture. Thereby, this helped us to identify the range of workability within the workability window diagram.

2. V-funnel time of the SCC mixtures incorporating metakaolin was higher than of the mixtures with SF or reference mixtures.

The minimum V-funnel time for VF1 classification should be $4 \mathrm{~s}$; otherwise concrete segregation would occur.

3. For the same slump flow diameter values, mixtures containing metakaolin or silica fume showed higher demand of HRWRA as compared to that of.

4. reference mixtures.

\section{Acknowledgment}

Authors are grateful for the support of Sika Corp. and Lafarge for providing the necessary materials.

\section{References}

[1] Okamura, H. - Ouchi, M. (2003): Self-Compacting Concrete. Journal of Advanced Concrete Technology. Vol. 1, pp. 5-15.

[2] ACI Committee 237. (2007): Self-Consolidating Concrete. American Concrete Institute.

[3] Bonen, D. - Shah, S. P. (2004): Fresh and hardened properties of selfconsolidating concrete. Progress on Structural Engineering and Materials. John Wiley \& Sons, Ltd. Vol. 7, pp. 14-26. https://doi.org/10.1002/pse.186

[4] The European Guidelines for Self-Compacting Concrete. (2002): Specification and Guidelines for Self-Compacting Concrete.

[5] The European Guidelines for Self-Compacting Concrete. (2005): Specification, Production and Use.

[6] Johari, M. A. M. - Brooks, J. J. - Kabir, S. - Rivard, P. (2011): Influence of supplementary cementitious materials on engineering properties of high strength concrete. Construction and Building Materials. Vol. 25, pp. 26392648. https://doi.org/10.1016/j.conbuildmat.2010.12.013

[7] BSI Standards Publication. (2010): Concrete. Part 9: Additional Rules for Self-compacting concrete (SCC). British Standard Institution. BS EN 2069:2010.

[8] BRL 1801. (2002): Aanvulling op de Nationale Beoordelingsrichtlijn Betonmortel betreffende het KOMO-productcertificaat voor Hoogvloeibare, verdichtungsarme en zelfverdichtende Betonmortel, Certificatie-instelling BMC, Gouda, The Netherlands (in Dutch).

[9] Domone, P. L. (2006): Self-compacting concrete: An analysis of 11 years of case studies. Cement and Concrete Composites. Vol. 28, pp. 197-208. https://doi.org/10.1016/j.cemconcomp.2005.10.003

[10] DAfStb. (2003): Richtlinie Selbstverdichtender Beton - Guideline for SCC, Deutscher Ausschuss für Stahlbeton (in German).
[11] El Mir, A. - Nehme, S. G. (2016): A comparative study on ultrasonic pulse velocity for normally vibrated and self-compacting concretes. Concrete Structures. Vol. 17, pp. 8-12.

[12] El Mir, A. - Nehme, S. G. (2017): Utilization of industrial waste perlite powder in self-compacting concrete. Journal of Cleaner Production. Vol. 156, pp. 507-517 https://doi.org/10.1016/j.jclepro.2017.04.103

[13] El Mir, A. - Nehme, S. G. (2015): Application of non-destructive test on self-compacting concrete, IABSE Symposium Report, I.A.B.S.E., vol. 105, pp. 1-8.

[14] El Mir, A. - Nehme, S. G. (2016): Comparison of durability performance of conventional and air-entrained self-compacting concrete modified by metakaolin and silica fume. Proceedings of the 8th International RILEM Symposium on Self-Compacting concrete, pp.61-71, Washington DC, U.S.A.

[15] El Mir, A. - Nehme, S. G. (2016): Application of chloride induced corrosion model for self-compacting concrete based on experimental data. Proceedings of the $11^{\text {th }}$ fib International PhD symposium in Civil Engineering, pp.191-198, Tokyo, Japan.

[16] BSI Standards Publication. (2010): Testing fresh concrete Part 8: Selfcompacting concrete - Slump-flow test. British Standard Institution. BS EN 12350-8:2010.

[17] BSI Standards Publication. (2010): Testing fresh concrete Part 9: Selfcompacting concrete - V-funnel test. British Standard Institution. BS EN 12350-9:2010.

[18] Madandoust, R. - Mousavi, S. (2012): Fresh and hardened properties of self-compacting concrete containing metakaolin. Construction and Building Materials. Vol. 35, pp. 752-760. https://doi.org/10.1016/j.conbuildmat.2012.04.109

[19] Hassan, A. - Lachemi, M. - Hossain, K. (2012): Effect of metakaolin and silica fume on the durability of self-consolidating concrete. Cement and Concrete Composites. Vol. 34, pp. 801-807. https://doi.org/10.1016/j.cemconcomp.2012.02.013

[20] Ahari, R. - Erdem,T. - Ramyar, K. (2015): Time-dependent rheological characteristics of self-consolidating concrete containing various mineral admixtures. Construction and Building Materials. Vol. 88, pp. 134-142. https://doi.org/10.1016/j.conbuildmat.2015.04.015

Ref.:

El Mir, Abdulkader - Nehme, Salem Georges: Assessment of the fresh self-compacting concrete properties utilizing different types of additives

Építőanyag - Journal of Silicate Based and Composite Materials, Vol. 69, No. 3 (2017), 83-88. p. https://doi.org/10.14382/epitoanyag-jsbcm.2017.14

Öntömörödő beton frissbeton-tulajdonságainak vizsgálata különböző kiegészítő anyagok alkalmazása esetén

Az öntömörödố betonok frissbeton tulajdonságai eltérnek a hagyományos betonokétól. Megfeleló beton összetétellel kell elérni, hogy a keverék homogén legyen, megfelelôen mozogjon, és ne osztályozódjon szét. Az öntömörödố beton sikeres alkalmazásához szükség van a megfelelố frissbeton tulajdonságokra a bedolgozás során. Az öntömörödô betonok elôállításának egyik legnagyobb kihívása az adott helyszínen elérhetố alapanyagok minôsége. Laboratóriumi kísérleteket végeztünk öntömörödô betonok reológiai tulajdonságainak vizsgálatára különbözô cement kiegészítô anyagokkal. Jelen cikk azt vizsgálja, hogy a különbözố cement kiegészítố anyagoknak milyen hatása van az öntömörödô betonok frissbeton tulajdonságaira. Az eredmények rávilágítottak, hogy a cement kiegészítô anyagok nagy hatást gyakorolnak a bedolgozhatóságra, és új elfogadási feltételek vezethetôk be erre vonatkozóan. 